\title{
STUDI FENOMENOLOGI: PENGALAMAN PRIMIPARA SAAT MENGALAMI DEPRESI POSTPARTUM
}

\author{
Puspita Palupi \\ Program Studi Ilmu Keperawatan FKIK UIN Syarif Hidayatullah Jakarta, Indonesia \\ E-mail: puspita.palupi@uinjkt.ac.id
}

\begin{abstract}
ABSTRAK
Latar belakang: Melahirkan umumnya merupakan suatu peristiwa yang menyenangkan, di sisi lain kehadiran anggota baru dalam kehidupan perempuan tidak selamanya merupakan kebahagiaan tersendiri. Perempuan yang mengalami kehamilan dan melahirkan memerlukan penyesuaian. Gangguan emosional dapat dialami oleh perempuan pasca persalinan seperti postpartum blues, depresi postpartum maupun psikosis postpartum. Tujuan: Penelitian ini bertujuan untuk mengeksplorasi pengalaman primipara saat mengalami depresi postpartum. Metode: Penelitian ini merupakan penelitian kualitatif dengan desain fenomenologi deskriptif. Data diperoleh melalui metode wawancara mendalam. Partisipan sejumlah enam orang meliputi primipara yang melahirkan secara spontan maupun dengan tindakan yang diperoleh melalui purposive sampling. Data yang dikumpulkan berupa hasil rekaman wawancara dan catatan lapangan. Data dianalisis dengan metode Collaizi. Hasil: didapatkan empat tema yaitu: (1) Melahirkan merupakan penderitaan dan membawa konsekuensi finansial; (2) Perubahan psikologis postpartum dan merasa menjadi orang yang berbeda dengan sebelumnya; (3) Ada hambatan dalam mengurus diri sendiri dan perawatan pada anak; dan (4) Ketidaksiapan menjadi ibu pada primipara. Simpulan: Hasil penelitian diharapkan dapat memberikan gambaran pada petugas kesehatan khususnya perawat maternitas tentang pentingnya memahami masalah gangguan adaptasi postpartum khususnya depresi postpartum pada primipara.
\end{abstract}

Kata Kunci: depresi postpartum, primipara, postpartum

\section{Phenomenological Study: the Experience of Primiparous Mother with Postpartum Depression ABSTRACT}

Background: Childbirth as a happy event, but on the other hand the presence of a new member in women's lives not always as a great pleasure. Women who experience pregnancy and childbirth require adjustment. Emotional disorders could be experienced by women after childbirth as postpartum blues, postpartum depression and postpartum psychosis. Objective: The objective of this study was to obtain the experience postpartum depression in primiparous. Method: This study used phenomenological descriptive design. Data were collected using in-depth interview method. The participants of this study were six primiparous mothers who giving birth either spontaneously or with other methods that obtained by purposive sampling. Data collected were interview recording and field notes. Data was analyzed using Collaizi techniques. This study identified four themes: (1) Delivery as a suffering and brought financial consequency; (2) Psychological change and felt like to be a different person; (3) Barriers in self care and child care; (4) Unreadiness to become primiparous mother. Discussion: Research result were expected to provide an overview to health care workers especially maternity nurses about the necessity to understand the problem of adaptation disorders, especially postpartum depression for primiparous mothers.

Keywords: postpartum depression, primiparous, postpartum 


\section{LATAR BELAKANG}

Masalah kesehatan perempuan yang begitu kompleks menuntut seluruh tenaga kesehatan profesional berkontribusi secara aktif termasuk perawat sebagai profesi kesehatan yang populasinya besar mempunyai kontribusi yang sangat strategis dalam membantu mengatasi berbagai permasalahan kesehatan reproduksi perempuan. Hal tersebut tentunya dapat membantu program pemerintah dalam upaya untuk menurunkan angka kematian ibu dan angka kematian bayi dan kesehatan reproduksi perempuan.

Lingkup pelayanan kesehatan maternal dan perinatal dalam pelayanan keperawatan maternitas yang diberikan meliputi pelayanan kepada ibu beserta bayinya dan perempuan dengan masalah kesehatan reproduksi di sepanjang siklus kehidupannya. Pelayanan yang diberikan dalam pelayanan maternal dan neonatal adalah pelayanan yang bermutu dalam menangani masalah fisik dan psikososialnya agar dapat membantu perempuan beradaptasi dalam seluruh siklus kehidupannya.

Kehamilan merupakan simbol terjadinya peralihan maturasi ke arah kedewasaan. Kehamilan dapat dikatakan sebagai ekspresi rasa perwujudan diri dan identitas sebagai perempuan (Hurlock, 2001). Melahirkan merupakan suatu peristiwa sangat penting yang dinantikan sebagian besar perempuan. Peran menjadi seorang ibu membuat perempuan merasa telah berfungsi utuh dalam menjalankan kehidupannya dan menambah rasa percaya diri di samping menjalani beberapa peran lainnya baik di dalam keluarga maupun di lingkungan sosial. Melahirkan merupakan suatu peristiwa sangat penting yang dinantikan sebagian besar perempuan. Umumnya melahirkan merupakan suatu peristiwa yang menyenangkan. Di sisi lain kehadiran anggota baru dalam kehidupan perempuan tidak selamanya merupakan kebahagiaan tersendiri. Perempuan yang mengalami kehamilan dan melahirkan memerlukan penyesuaian.

Kebahagiaan mungkin tidak akan dirasakan oleh sebagian ibu yang tidak berhasil menyesuaikan diri terhadap sejumlah faktor perubahan yang terjadi. Peran menjadi seorang ibu membuat perempuan merasa telah berfungsi utuh dalam menjalankan kehidupannya dan menambah rasa percaya diri di samping menjalani beberapa peran lainnya baik di dalam keluarga maupun di lingkungan social (Levi, 2003).

Perasaan menjadi seorang ibu baru berbeda-beda, pada umumnya akan merasa takjub melihat bayinya, tidak pernah merasakan lelah, dan bersemangat merawat bayinya. Sebagian perempuan justru merasakan sebaliknya yaitu merasa sedih, marah, kesal, lelah, tidak berarti, dan putus asa dalam menjalani hari setelah melahirkan. Kondisi perasaan yang diikuti dengan rasa enggan mengurus bayi bahkan ingin membunuh bayinya dikenal dengan depresi postpartum. Mereka dapat mengalami berbagai gangguan emosional pasca persalinan yang terbagi dalam tiga bentuk yaitu postpartum blues, depresi postpartum dan psikosis postpartum (Elvira, 2006; Bobak, Lowdermilk \& Jensen, 2004).

Depresi postpartum merupakan gangguan suasana hati pada ibu postpartum yang terjadi dalam empat minggu setelah melahirkan dan bisa berlanjut sampai dengan setahun yang ditandai dengan dipenuhi rasa sedih, menangis tanpa sebab, gangguan tidur dan labilitas afek. Kondisi yang lebih ringan dari depresi postpartum disebut dengan postpartum blues. Pada kondisi ini, perempuan tersebut mengalami tandatanda sebagaimana pada depresi postpartum hanya saja dalam intensitas yang lebih ringan dan dalam rentang waktu yang lebih pendek (Spong, dkk, 2009).

Kondisi yang lebih berat dari depresi postpartum adalah postpartum psikosis. 
Banyak faktor yang diduga berperan pada terjadinya depresi postpartum, antara lain adalah faktor hormonal, umur, paritas, pengalaman dalam proses kehamilan dan persalinan, tingkat pendidikan, status perkawinan, kehamilan yang tidak diinginkan, riwayat gangguan kejiwaan sebelumnya, sosial ekonomi, dan keadekuatan dukungan sosial dari lingkungannya (Hanna, Jarman, \& Savage, 2004).

Melihat ketiga gangguan psikologis pospartum, masalah yang paling penting pada gangguan psikologis postpartum adalah depresi postpartum, mengingat angka kejadiannya yang tinggi dan penatalaksanaan yang salah dapat mengakibatkan gangguan jiwa yang serius. Hasil penelitian menunjukkan bahwa kasus ini dialami oleh lebih kurang $15-20 \%$ dari perempuan yang melahirkan pertama kali. Angka kejadian di Malaysia pada 1995 sebanyak 3,9\% sedangkan di Singapura angka kejadiannya hanya $1 \%$. Data angka kejadian di Indonesia menunjukkan lebih rendah dari masyarakat di dunia mengingat budaya Indonesia yang diasumsikan lebih sabar dan dapat menerima apapun yang dialaminya.

Centers for Disease Control and Prevention $(C D C)$ melaporkan bahwa prevalensi depresi postpartum berkisar antara $11,7 \%$ sampai $20,4 \%$ pada tahun 2004-2005. Jika kondisi ini tidak ditangani dengan baik, maka dapat berkembang menjadi psikosis postpartum dengan prevalensi 0,10,2\% (Barclay, dkk, 1997). Penelitian yang dilakukan di Osaka, Jepang, pada tahun 2010 dengan jumlah responden sebanyak 771 orang yang menghubungkan pekerjaan, penghasilan, dan pendidikan dengan kejadian depresi postpartum mendapat hasil prevalensi postpartum sebanyak $13,8 \%$ (Miyake, dkk, 2011). Hasil penelitian yang dilakukan tahun 2009 pada 50 orang ibu postpartum spontan di bangsal rawat inap RSUP Haji Adam Malik Medan didapatkan hasil perempuan postpartum yang mendapatkan sindrom depresi postpartum sebanyak $16 \%$ dan yang tidak mengalami depresi postpartum sebanyak $84 \%$ (Sari, 2009).

Depresi postpartum yang merupakan tekanan emosional setelah melahirkan sering terjadi pada seorang yang baru pertama kali menjadi seorang ibu (primipara). Seorang primipara akan merasa sangat tidak berdaya dan kurang mampu serta memiliki perasaan terbebani oleh tanggung jawab terhadap bayi dan keluarganya. Kondisi seperti ini bila dibiarkan dan tidak diatasi segera akan berdampak buruk bagi ibu dan bayinya, apalagi bagi perkembangan kepribadian anak, dan dapat memengaruhi hubungan suami istri dalam lingkup yang luas bahkan dapat memengaruhi keutuhan rumah tangga.

Konsekuensi dari depresi postpartum mempunyai efek yang merusak (negative effect) hubungan interaksi antara bayi dan ibu dalam tahun pertama kehidupan mereka. Ibu akan mengalami kesulitan dalam mengasuh serta menjalin ikatan emosional yang memadai terhadap bayi maupun anaknya yang lain. Bayi-bayi dari ibu yang mengalami depresi dilaporkan menunjukkan perilaku yang lebih rewel, mudah menangis dan kurang berespon terhadap rangsangan yang diberikan kepadanya. Bagi ibu sendiri, dalam kondisi berat bisa memunculkan keinginan untuk mengakhiri penderitaan lewat jalan yang membahayakan diri maupun anaknya (Beck, \& Indman, 2005).

Permasalahan depresi postpartum telah banyak diteliti dari berbagai sudut pandang. Terdapat fenomena depresi postpartum di Indonesia yang masih belum banyak tereksplorasi secara mendalam mengenai pengalaman saat depresi postpartum baik dari ungkapan atau cerita langsung dari para ibu primipara. Oleh karena itu penelitian ini mengeksplorasi fenomena pengalaman depresi postpartum pada ibu primipara 
sehingga dapat mengungkap berbagai hal yang dialami terkait dengan gangguan penyesuaian postpartum khususnya depresi postpartum yang dialaminya.

\section{METODE}

Penelitian ini menggunakan metode kualitatif dengan pendekatan fenomenologi deskriptif yang bertujuan untuk menggali pengalaman primipara saat mengalami depresi postpartum. Penelitian dilakukan di wilayah kerja Puskesmas Pasar Rebo. Partisipan dalam penelitian ini yang mengalami masalah gangguan penyesuaian postpartum pada minggu kedua sampai minggu kedelapan postpartum dengan skor lebih dari 9 menggunakan instrumen Beck Depression Inventory (BDI). Penelitian dilakukan pada bulan Mei sampai dengan Oktober 2015.

Metode pengumpulan data dengan wawancara mendalam dan catatan lapangan. Analisis data pada penelitian ini berdasarkan tahap analisis data menurut Colaizzi (1978) dikutip dari Streubert \& Carpenter (2011). Data rekaman hasil wawancara diubah dalam bentuk tertulis (transkrip), kemudian diidentifikasi kata kunci, menggabungkan kata kunci yang sama dalam bentuk kategori, menentukan sub-sub tema, kemudian tema-tema potensial, melakukan validasi ke partisipan, dan menentukan tema akhir penelitian.

Peneliti menerapkan beberapa prinsip etik yaitu prinsip manfaat (beneficence), prinsip menghargai hak asasi manusia (respect human dignity), dan prinsip keadilan (right to justice). Pertimbangan etik lainnya yang telah dilakukan oleh peneliti adalah menjaga kerahasiaan (confidentiality) dan anonimitas (annonimity) partisipan baik dalam pengumpulan data maupun penyajian hasil penelitian.

\section{HASIL}

Sebanyak enam partisipan berpartisipasi dalam penelitian ini. Mereka bertempat tinggal di beberapa wilayah di Kecamatan Pasar Rebo. Karakteristik partisipan sebagai berikut:

\section{Partisipan 1}

Ny T, 40 tahun, post seksio sesaria atas indikasi preeklampsia berat dan letak sungsang, P1A0, ibu rumah tangga, Islam, Sunda, menikah, SMP, telah melahirkan bayi laki-laki 8 minggu yang lalu. Bayi lahir prematur pada umur kehamilan 30 minggu, berat lahir 1.000 gram. Suami Tn. R, 51 tahun, SMP, pekerjaan sebagai buruh di pasar.

\section{Partisipan 2}

Ny. D, 40 tahun, P1A0, SD, ibu rumah tangga, Sunda, Islam, pernikahan yang pertama, telah melahirkan bayi laki-laki 8 minggu yang lalu secara normal dengan episiotomi. Bayi lahir cukup bulan, berat lahir 2.700 gram, anak mengalami gangguan pada saluran empedu. Suami telah meninggal dunia setahun yang lalu karena penyakit liver.

\section{Partisipan 3}

Ny $R, 30$ tahun, P1A0, post seksio sesaria atas indikasi ketuban pecah dini, ibu rumah tangga, Islam, Jawa, menikah, SD, telah melahirkan bayi perempuan 6 minggu yang lalu, lahir prematur 33 minggu, dan berat lahir 1.800 gram. Suami, Tn R, 31 tahun, SD, pedagang.

\section{Partisipan 4}

Ny $P, 34$ tahun, post seksio sesaria atas indikasi letak sungsang P1A0, guru, Islam, Sunda, menikah, DIII, telah melahirkan bayi laki-laki 4 minggu yang lalu, bayi lahir cukup bulan, berat lahir 2800 gram. Suami Tn. F, 38 tahun, STM, karyawan swasta. 


\section{Partisipan 5}

Ny $B, 20$ tahun, P1A0, ibu rumah tangga, Islam, Jawa, menikah, SMA, telah melahirkan bayi laki-laki secara normal dengan episiotomi 4 minggu yang lalu, bayi lahir normal. Suami Tn. A, 20 tahun, SMA, swasta.

\section{Partisipan 6}

Ny I, 19 tahun, P1A0 post seksio sesaria atas indikasi preeklampsia berat, ibu rumah tangga, Islam, Jawa, menikah, SMP, telah melahirkan bayi perempuan 8 minggu yang lalu, bayi lahir prematur 34 minggu, berat lahir 2.000 gram, kondisi bayi saat ini sehat. Suami Tn T, 21 tahun, SMP, sopir.

Hasil analisis tematik ini menjelaskan tema yang ditemukan pada penelitian ini. Berbagai tema yang diperoleh terkait dengan pengalaman primipara saat mengalami depresi postpartum meliputi: (1) Melahirkan merupakan penderitaan dan membawa konsekuensi finansial; (2) Perubahan psikologis postpartum dan merasa menjadi orang yang berbeda dengan sebelumnya; (3) Ada hambatan dalam mengurus diri sendiri dan perawatan pada anak; dan (4) Ketidaksiapan menjadi ibu pada primipara.

1. Melahirkan merupakan penderitaan dan membawa konsekuensi finansial

Makna melahirkan mencakup semua makna yang berkaitan dengan semua hal yang terkait arti melahirkan bagi ibu primipara. Pada studi ini terdapat beberapa makna melahirkan bagi ibu primipara yang meliputi sebagai penderitaan hidup keluarga, bentuk kehancuran masa depan, dan beban ekonomi keluarga.

a. Penderitaan hidup keluarga

Semua partisipan mengungkapkan bahwa melahirkan dianggap sebagai penderitaan bagi hidup keluarga karena ketidaksiapan untuk menerima kelahiran sang anak, seperti ungkapan partisipan berikut ini:

“......menurut saya saat saya habis melahirkan, melahirkan itu bagaikan penderitaan bagi saya dalam keluarga........."(P2)

......saya merasa sudah tua dan gak mau punya anak karena sudah gak mampu lagi ngerawat anak..." (P1)

b. Bentuk kehancuran masa depan Dua dari enam partisipan mengungkapkan bahwa melahirkan dianggap sebagai bentuk kehancuran bagi masa depan. Hal ini karena usia masih terlalu muda: Berikut salah satu ungkapan yang disampaikan partisipan:

"....berat bagi saya jalani kehidupan dengan punya anak, padahal saya masih pengin sekolah, saya coba gugurin anak saya waktu itu tapi gak berhasil........"(P6)

c. Beban ekonomi keluarga

Semua partisipan mengungkapkan bahwa memiliki anak adalah sebagai beban berat secara ekonomi di keluarga. Dalam hal ini hadirnya anak menyebabkan kebutuhan di keluarga juga meningkat dan pengeluaran juga bertambah. Berikut ini salah satu ungkapan partisipan:

“.....saya berat untuk membiayai anak yang lahir ini karena kemampuan ekonomi saya ...." (P1)

\section{Perubahan psikologis postpartum dan merasa menjadi orang yang berbeda dengan sebelumnya}

Perubahan psikologis berupa konflik tentang kemampuan perempuan menjadi seorang ibu, perasaan bingung antara penerimaan dan penolakan terhadap 
peran baru sebagai ibu, permasalahan komunikasi dengan bayi dan pasangan. Dalam studi ini perubahan psikologis yang dialami ibu primipara meliputi sedih berkepanjangan, sering menangis, suasana hati tidak menentu, dan mudah tersinggung.

a. Sedih berkepanjangan

Semua partisipan dalam studi ini mengungkapkan setelah melahirkan menjadi pribadi yang sedih setiap saat sampai beberapa bulan setelahnya. Perasaan sedih terkadang tidak dapat dipahami oleh keluarga. Berikut ini salah satu ungkapan partisipan:

“.......hampir setiap saat saya merasa sedih setelah melahirkan, ditambah tidak ada satupun orang yang mau memahaminya...." (P6)

b. Suasana hati tidak menentu

Semua partisipan mengalami berbagai perasaan tidak menentu setelah melahirkan. Semua partisipan sering menangis sepanjang hari karena menyesali keadaan yang telah terjadi setelah melahirkan. Berikut salah satu ungkapannya:

"........saya telah melahirkan anak yang gak sama seperti orang lainnya bayi saya kecil, hal ini juga telah membuat saya sering menangis "(P3)

Pengalaman lain diungkapkan oleh partisipan bahwa dirinya sering menangis tanpa sebab yang jelas sehabis melahirkan anaknya. Berikut ini ungkapannya:

“......entah kenapa saya menjadi orang yang sangat berbeda karena jadi gampang menangis setelah melahirkan......."(P5)

Pengalaman yang dirasakan oleh semua partisipan yaitu mudah tersinggung dalam segala hal.
Berikut ini salah satu ungkapannya: “........sejak melahirkan itu saya sering banget tersinggung sama siapapun di rumah termasuk suami......" (P6)

c. Tidak mau mengurus anak Stressor psikososial adalah suatu peristiwa atau kejadian yang mengakibatkan seseorang harus melakukan penyesuaian atau adaptasi terhadap kondisi yang dialaminya. Peristiwa yang terjadi tersebut menyebabkan keadaan semula stabil terpaksa harus disesuaikan. Lima dari enam partisipan mengungkapkan dirinya enggan sekali untuk mengurus anaknya. Berikut ini salah satu ungkapan partisipan:

“....untuk mengurus diri sendiri saja saya merasa berat apalagi saya harus mengurus anak saya...." (P2)

\section{Ada hambatan dalam mengurus diri sendiri dan perawatan pada anak}

Semua partisipan mengeluhkan bahwa mereka merasa susah untuk merawat anaknya. Sulit berpikir untuk merawat anak, perawatan untuk diri sendiri pun dirasakan sulit.

a. Kondisi anak tidak normal

Empat dari enam orang partisipan mengungkapkan bahwa hal yang membuat dia enggan dalam merawat anak karena kondisi anak saat lahir yang tidak normal, sehingga semakin saja membuat ibu menjadi malas untuk merawat anak. Berikut ini ungkapan pengalamannya:

".......berat banget habis lahiran ,mengurus anak yang kondisinya gak normal, banyak aturan dokter juga...." (P2)

Semua partisipan juga mengeluh 
adanya pengeluaran biaya yang berlebih karena kondisi anak memerlukan pengawasan dan perawatan khusus. Berikut ini salah satu ungkapannya:

“...........saya stress banget kalo harus keluar biaya buat rawat anak, padahal hidup saya pas-pasan aja buat sehari-hari........." (P1)

b. Belum mengerti cara merawat anak Empat dari enam partisipan mengungkapkan bahwa mereka sudah stress dengan proses melahirkan ditambah masih belum memahami bagaimana cara merawat anak. Berikut ini salah satu ungkapannya: “............gimana saya gak mau ngerawat anak, habis melahirkan aja gak nyaman, ditambah saya belum ngerti gmn cara ngerawat anak yang baru lahir.........." (P6)

\section{Ketidaksiapan menjadi ibu pada primipara}

Semua partisipan dalam studi ini mengungkapkan ketidaksiapan menjadi peran ibu, meskipun dari usia sudah cukup mampu menjalani perannya. Semua partisipan mengungkapkan bahwa belum ada kesiapan menjadi ibu yang nantinya memiliki banyak peran setelah melahirkan. Berikut ini salah satu ungkapannya:

“............meski umur udah tua, tapi saya udah gak mau jadi ibu karena tadinya hanya mau menikmati sisa umur yang udah tua ini...." (P1)

\section{DISKUSI}

Melahirkan merupakan peristiwa yang sangat berharga dalam hidup seorang perempuan. Peristiwa ini merupakan masa transisi yang dapat menyebabkan terjadinya krisis kehidupan pada ibu dan keluarga. Pe- rubahan peran menjadi seorang ibu memerlukan adaptasi yang harus dijalani, membentuk sebuah adaptasi yang cukup kompleks. Ibu tidak hanya mengalami perubahan fisik namun juga psikologisnya yang dapat mengakibatkan gangguan emosional. Beberapa perempuan mengalami kecemasan atau bahkan depresi setelah melahirkan.

Hasil penelitian ini menunjukkan bahwa pengalaman primipara saat mengalami depresi postpartum meliputi proses adaptasi peran menjadi seorang ibu, proses adaptasi psikologis masa postpartum, dan sistem pendukung bagi ibu.

\section{Proses adaptasi psikologis postpartum}

Masa nifas memerlukan proses adaptasi baik fisiologis maupun psikologis. Menjadi orang tua merupakan suatu krisis tersendiri dan harus melewati masa transisi. Perubahan psikologis masa postpartum akan dikuti oleh perubahan psikologis secara simultan sehingga ibu harus beradaptasi secara menyeluruh.

Hasil penelitian ini menunjukkan bahwa melahirkan dianggap sebagai hal yang tidak menyenangkan yang ditunjukkan sebagai penderitaan, kehancuran masa depan dan beban ekonomi keluarga. Melahirkan dianggap sebagai proses yang sangat tidak diharapkan dan mengecewakan. Sejalan dengan penelitian yang dilakukan oleh Coates, Ayers, \& de Visser tahun 2014 di London.

Di sisi lain, menjadi seorang ibu dapat dipengaruhi oleh umur dan proses melahirkan seperti yang diungkapkan oleh Mercer \& Walker (2006). Partisipan dalam penelitian ini berada pada rentang umur 19 sampai dengan 40 tahun. Umur yang sangat muda merupakan salah satu faktor predisposisi dari depresi postpartum, karena umur yang sangat muda akan memengaruhi kesiapannya berperan sebagai ibu. Hal ini sesuai dengan pendapat McKinney, dkk 
(2017) yang mengatakan bahwa kehamilan remaja memengaruhi kemampuannya dalam menjalankan peran sebagai orang tua dan dapat memengaruhi terjadinya depresi postpartum. Semua partisipan merupakan umur risiko tinggi untuk melahirkan. Hal ini menunjukkan bahwa banyak faktor lain yang bisa menyebabkan depresi postpartum.

Riwayat melahirkan pada penelitian ini meliputi dua partisipan melahirkan secara spontan dengan dilakukan episiotomi dan empat partisipan persalinan dilakukan dengan sectio sesaria. Riwayat melahirkan dan stressor pada masa intranatal seperti induksi persalinan, laserasi perineum, kala dua memanjang dan persalinan dengan seksio sesaria merupakan salah satu predisposisi terjadinya depresi postpartum pada minggu keenam (Beck, 2001). Depresi postpartum berkaitan dengan status paritas adalah riwayat obstetrik pasien yang meliputi riwayat hamil sampai bersalin serta apakah ada komplikasi dari kehamilan dan persalinan sebelumnya dan terjadi lebih banyak pada perempuan primipara. Perempuan primipara lebih umum menderita blues karena setelah melahirkan perempuan primipara berada dalam proses adaptasi. Kalau dulu hanya memikirkan diri sendiri, begitu bayi lahir, jika ibu tidak paham perannya, ia akan menjadi bingung sementara bayinya harus tetap diberikan perawatan.

\section{Proses adaptasi psikologis masa postpartum}

Adaptasi psikologis terjadi jika memiliki pengalaman yang baik terhadap persalinan. Pada penelitian ini semua partisipan yang dikelola berstatus sosial ekonomi menengah ke bawah, mereka menggunakan kartu tidak mampu, dan kartu BPJS (Badan Penyelenggara Jaminan Sosial). Kondisi sosial ekonomi yang rendah merupakan salah satu faktor yang signifikan bagi seseorang untuk mengalami kejadian depresi postpartum (Beck,
2002; O'Hara \& Swain, 1996; Lee, dkk, 2000; Patel, Rodrigues, \& DeSouza, (2002).

Semua partisipan menjalani kehamilan yang tidak diinginkan. Sebanyak satu partisipan mengalami stress masa prenatal karena suami meninggal dunia. Suami dari empat partisipan tidak terlibat dalam proses persalinan. Dua partisipan mengalami kehamilan di luar nikah dan pernikahan yang tidak disetujui oleh orang tuanya. Hal ini sesuai dengan pendapat peneliti sebelumnya bahwa peristiwa yang menekan seperti single parent, dukungan suami yang kurang dalam proses persalinan bisa memengaruhi depresi postpartum (Bobak, Lowdermilk \& Jensen, 2004). Mereka mengatakan bahwa ketidakmampuan menjalankan peran sebagai orang tua memengaruhi terjadinya depresi postpartum, dimana hal ini antara lain dipengaruhi oleh kehamilan yang tidak diinginkan, hamil di luar nikah, dan usia terlalu muda.

Beck (2006) menyatakan bahwa sistem pendukung bagi klien akan sangat bermakna dalam membantu klien mencegah depresi postpartum. Semua partisipan mengungkapkan bahwa dukungan dari suami tidak terlihat jelas bahkan tidak memberikan dukungan selama perawatan bayi, sehingga sulit bagi partisipan untuk menerima peran baru dan menerima kenyataan (Pilliteri, 2003).

\section{SIMPULAN}

Depresi postpartum adalah gangguan emosional pasca persalinan yang bervariasi, terjadi pada 10 hari pertama masa setelah melahirkan dan berlangsung terus-menerus sampai 6 bulan bahkan sampai satu tahun. Faktor penyebab depresi postpartum adalah faktor konstitusional, faktor fisik yang terjadi karena adanya ketidakseimbangan hormonal, faktor psikologi, faktor sosial dan karakteristik ibu, dengan gejala-gejalanya antara lain adalah trauma terhadap 
intervensi medis yang dialami, kelelahan, perubahan mood, gangguan nafsu makan, gangguan tidur, tidak mau berhubungan dengan orang lain, tidak mencintai bayinya, ingin menyakiti bayi atau dirinya sendiri atau keduanya. Diharapkan perawat dapat lebih meningkatkan kesehatan maternal pada ibu postpartum dan bayinya khususnya pengembangan program-program health promotion mengenai kesehatan maternal area postpartum.

\section{DAFTAR PUSTAKA}

Barclay, L., Everett, L., Rogan, F., Schmied, V., Wyllie, A. (1997). Becoming a mother-An analysis of women's experience of early motherhood. Journal of Advanced Nursing, 25: 719-728.

Beck, C.T. (2001). Predictors of Postpartum Depression: an update. Nursing Research, 50: 275-285.

Beck, C.T. (2002). Postpartum depression: a metasynthesis. Qualitative Health Research, 12: 453-472.

Beck \& C. T. (2006). Postpartum depression: It isn't just the blues. American Journal of Nursing, 106(5): 40-50.

Beck, C. T. \& Indman, P. (2005). The many faces of postpartum depression. Journal of Obstetric, Gynecology, \& Neonatal Nursing, 34(5): 569-576.

Bobak, Lowdermilk \& Jensen (2004). Keperawatan maternitas. Jakarta: EGC.

Coates, R., Ayers, S., \& de Visser, R. (2014). Women's experiences of postnatal distress: a qualitative study. $B M C$ pregnancy and childbirth, 14(1): 359.

Elvira, D., S. (2006). Depresi pasca persalinan. Jakarta: Fakultas Kedokteran Universitas Indonesia.

Hanna, B., Jarman, H., \& Savage, S. (2004). The clinical application for three screening tools for recognizing post- partum depression. International Journal of Nursing Practice, 10(2): 72-79.

Hurlock, E. B. (2001). Psikolog perkembangan: suatu pendekatan sepanjang rentang kehidupan. Jakarta: Erlangga.

Levi, M. (2003). Organizing power: The prospects for an American labor movement. Perspectives on Politics, 1(1): 45-68.

Lee, D. T., Yip, A. S., Leung, T. Y, \& Chung, T. K. (2000). Identifying women at risk of postnatal depression: Prospective longitudinal study. Hong Kong Med J, 6(4): 349-354.

McKinney, E. S., James S. R., Murray, S. S., Nelson, K., Ashwill, J. (2017). Maternal-child nursing e-book. Elsevier Health Sciences.

Mercer, R. T., \& Walker, L. O. (2006). A review of nursing interventions to foster becoming a mother. Journal of Obstetric, Gynecologic \& Neonatal Nursing, 35(5): 568-582.

Miyake, Y., Tanaka, K., Sasaki, S., \& Hirota, Y. (2011). Employment, income, and education and risk of postpartum depression: the Osaka Maternal and Child Health Study. Journal of affective disorders, 130(1-2): 133-137.

Patel, V., Rodrigues, M., \& DeSouza, N. (2002). Gender, Poverty, and Postnatal Depression: A Study of Mothers in Goa, India. American Journal of Psychiatry, 159: 43-47.

Pilliteri, A. (2003). Maternal and child health nursing. Philadelphia: Lippincott.

Sari, L. S. (2009). Sindroma Depresi Pasca Persalinan Di Rumah Sakit Umum Pusat Haji Adam Malik Medan (Tesis). Universitas Sumatera Utara, Medan, Indonesia. 
Spong, C. Y., Cunningham, F., Leveno, K., Bloom, S., Hauth, J., \& Rouse, D. (2009). Williams obstetrics. New York: McGraw-Hill Education.

Streubert, H. J., \& Carpenter, D. R. (2011). Qualitative research in nursing: Advancing the humanistic imperative, $5^{\text {th }}$ ed. Philadelphia: Lippincot William \& Wilkins A Wolters Kluwer Company. 